\title{
Erratum to: Reductive metabolism of the dinitrobenzamide mustard anticancer prodrug PR-104 in mice
}

\author{
Yongchuan Gu $\cdot$ Christopher P. Guise - Kashyap Patel • \\ Maria R. Abbattista · Jie Li - Xueying Sun - Graham J. Atwell • \\ Maruta Boyd · Adam V. Patterson · William R. Wilson
}

Published online: 19 March 2011

(C) Springer-Verlag 2011

Erratum to: Cancer Chemother Pharmacol (2011)

\section{7:543-555}

DOI 10.1007/s00280-010-1354-5

Author would like to correct one of the misspelled authors name in the published article. The correct name should be Jie Li.

The online version of the original article can be found under doi:10.1007/s00280-010-1354-5.

Y. Gu · C. P. Guise - K. Patel - M. R. Abbattista - J. Li .

G. J. Atwell · M. Boyd · A. V. Patterson - W. R. Wilson ( $\square)$

Auckland Cancer Society Research Centre,

Faculty of Medical and Health Sciences,

The University of Auckland, Private Bag 92019,

Auckland, New Zealand

e-mail:wr.wilson@auckland.ac.nz

\section{Sun}

Department of Molecular Medicine and Pathology,

Faculty of Medical and Health Sciences,

The University of Auckland, Auckland, New Zealand 